\title{
Rehberlik ve Psikolojik Danıșmanlık Öğrencilerinin Kuramlara Hakimiyetlerinin ve Karar Verme Stratejilerinin İncelenmesi
}

\author{
Gökhan isKiFOČLU* \\ Tubanur ÇELIK ISKIFOĞLU*
}

Öz: Bu araştırmada, mezuniyet aşamasına gelmiş Rehberlik ve Psikolojik Danışma programı öğrencilerinin, bireyle psikolojik danışma hakimiyetleri ve karar verme stratejileri farklı bağımsız değişkenler göz önünde bulundurularak incelenmiştir. İncelenen veriler 2017-2018 Bahar döneminde Kuzey Kıbrıs'ta özel bir üniversitede mezuniyet aşamasına gelmiş son sinıf Rehber ve Psikolojik Danışman adaylarından toplanmıştır. Araştırmanın örneklemi 52'si kadın, 52'si erkek olmak üzere 104 kişiden oluşmuştur. Veriler SPSS programı yardımıyla analiz edilmiş olup değişkenlerin türüne göre bağımsız gruplar t-testi, tek örneklemli t-testi ve tek yönlü varyans analizi sayısal çözümleme teknikleri kullanılmıştır. Analiz sonuçlarına göre katılımcıların bireyle psikolojik danışmanlık kuramlarına ilişkin performanslarının literatürün belirlediği standartlardan anlamlı düzeyde düşük olduğu saptanmıştır. Bu bulguya rağmen, katılımcıların en iyi performans gösterdikleri kuramın Psikanalitik Kuram olduğu görülürken, karar verme stratejileri açısından değerlendirildiğinde katılımcıların henüz belli bir karar stratejisine sahip olmadıkları bulunmuştur. Bu makale kapsamında, ölçülen bağımlı değişkenler açısından katılımcıların yeterlik düzeylerinin düşük olmasının sebepleri literatür desteğiyle tartışılmış ve öneriler sunulmuştur.

Anahtar Sözcükler: Psikolojik Danışman Yeterlikleri, Bireyle Psikolojik Danışmanlık, Karar Stratejileri

\section{Competency Levels and Decision Making Strategies of Guidance and Psychological Counseling Students}

\begin{abstract}
This research investigated the performances of senior level psychological guidance and counseling students regarding their individual counseling theories and decision-making strategies in terms of various independent variables. The data processed under the mainstream of this study was collected from near graduate senior level psychological counseling and guidance students in a private university in Turkish Republic of Northern Cyprus (TRNC) in 2017-2018 spring academic term. The sample was 104 individuals and composed of 52 male and 52 female participants. Participants' performances regarding to the individual counseling theories were found to be significantly lower than the minimum competency parameters defined by the related literature. However, the participants mostly performed better at Psychoanalytic Theory among the other theories considered for that study. When taken from the perspective of decision-making strategies of the participants, the findings showed that participants actually do not belong to any defined categories of decision making defined by Kuzgun.
\end{abstract}

Keywords: Psychological Counseling Competencies, Individual Counseling Theories, Decision-making Strategies

* Lefke Avrupa Üniversitesi, Eğitim Fakültesi, Sınıf Öğretmenliği Bölümü, Lefke, KKTC, e-posta: giskifoglu@eul.edu.tr, ORCID: https://orcid.org/0000-0001-8119-4254

${ }^{* * *}$ Kıbrıs Sosyal Bilimler Üniversitesi, Eğitim Bilimleri Fakültesi, Rehberlik ve Psikolojik Danışmanlık Bölümü, Lefkoşa, KKTC, e-posta: tubanur.celik@kisbu.edu.tr, ORCID: https://orcid.org/0000-0002-7661-205X 
Rehberlik ve Psikolojik Danışmanlık (RPD) bölümü öğrencilerinin mezuniyet sonrası kariyer planlarının çok çeşitli olduğu bilinmektedir (Sarıkaya ve Khorsid, 2009). Bunlar; psikolojik danışma merkezi açmaktan okullarda okul danışmanlığı veya kariyer danışmanlığı hizmeti vermeye, yüksek lisans ve doktora yapıp üniversitelerde eğitim vermekten, öğretim üyesi olarak görev almaya, serbest araştırmacı olmaktan, aile danışmanlığı yapmaya ve daha birçok danışmanlık hizmet alanlarına kadar çok geniş bir yelpazeyi içeren kariyer ağını içerir (Bilgin, 2000; Doğan, 2000a; Yeşilyaprak, 2009). RPD bölümü öğrencilerinin mezun olduktan sonra alabilecekleri olası bu vazifelerde gösterecekleri başarı toplumun ve örgün eğitim sistemi içerisinde öğrenim gören öğrencilerin başarılarını olumlu yönde etkileyecektir (Gladding, 2013; Niles ve Bowlsbey 2013). Kuşkusuz iyi bir danışmanlık hizmeti almış ilköğretim ve lise öğrencileri meslek seçimlerinde ve daha mutlu bir birey olma yolunda emin adımlarla ilerleyecektir (Hatipoğlu, 2010; Kuzgun, 2000, 2011). İyi bir aile danışmanlığ anlayacaklar ve daha mutlu olacaklardır (Alver, 2004). Bu, hem bireylerin hem toplumun sağlıklı gelişimi için önemlidir. Sağlıklı aile sağlıklı bireyler yetiştirecek ve toplumsal düzen bu durumdan olumlu yönde etkilenecektir. Bahsedilen bu açılardan rehber ve psikolojik danışmanların başarılı olmaları büyük ölçüde üniversitede aldıkları eğitimin kalitesine ve orada atılan akademik temele bağlıdır (Gibson ve Mitchell, 1990; Sharf, 2014; Owen, Acar, Avcı ve Kızıldağ, 2013). Birçok araştırmacı, RPD uzmanlarının mesleklerini etkili icra edebilmelerinin üniversitede kazanacakları bazı kritik bilgi ve becerilere bağlı olduğunu savunmaktadırlar (Atıcı ve Çam, 2013; Egan, 2011). Araştırmalar, bahsi geçen bu kritik bilgi ve becerilerin bireylerin meslek hayatları boyunca edinecekleri tecrübeleri inşa edecekleri zemin olduğunu önemle vurgulamaktadırlar. Öyle ki bu kritik bilgi ve beceriler açısından temeli sağlam olmayan bir kariyerin ne bireylere ne de topluma faydası olmayacağı görüşü literatürde ciddi yer tutmaktadır (Sharpley ve Ridgway, 1991; Owen, Dost ve Bugay, 2014).

Toplum ve bireyler için ciddi önem arz eden RPD hizmetinin belli standartlar dahilinde verilebilmesini, üniversitede kazanılması gereken bazı kritik bilgi ve becerilere bağlayan literatür bu bilgi ve becerilerinin en önemli iki tanesini sırasıyla (1) psikolojik danışma kuramlarına olan hakimiyetlerine (Meydan, 2015; Pamuk 2012; Öncü, 2015; Öztürk, 2014; Özyürek 2009; Yaka, 2005), (2) karar verme stratejilerine (Avşaroğlu, 2007; Eldeleklioğlu, 1999; Kuzgun, 1993; Tiryaki, 1997) bağlamaktadır. Karar stratejisi, psikolojik danışmana teşhis koyarken terapötik süreçlerde sorulacak soruların seçimi, dinlerken algılanan bilginin içeriğininin ve tavsiye niteliği taşıyan önerilerin belirlenmesi gibi önemli durumlarda yol göstericidir (Tyburski, 2017). Terapi süreçlerinin niteliği psikolojik danışmanın sahip olduğu karar stratejisine bağlıdır (Hastie ve Dawes, 2010). İster boşanma arifesindeki bir çifte veya aile içi iletişim sorunları yaşayan bir gence verilecek olan aile danışmanlığı hizmeti olsun, ister kafası karışık bir gence verilecek olan kariyer danışmanlığı hizmeti olsun, psikolojik danışmanın sorunun temeline inip doğru danışmanlık süreci başlatması, etkili bir şekilde devamını getirmesi, süreç içerisinde nereye nasıl müdahale etmesi gerektiğini bilebilmesi ve süreci nasıl başarılı bir şekilde sonlandırması gerektiğine karar verebilmesi bahsedilen bu kritik bilgi ve becerilere bağlıdır (Kuzgun, 1993; Öncü, 2015).

Konu alanıyla ilgili son yıllarda yapılmış çalışmalar, eğitim fakültelerinin RPD bölümünün müfredatı, işleyişi, ders içerikleri, yöntemleri, materyalleri ve imkânlarıyla RPD öğrencilerine bu kritik bilgi ve becerileri kazandırması açısından gereken imkânları sağlaması ve öğrencilerin kendilerini bu açılardan geliştirmesi için gerekli çabanın önemini vurgulayıcı birçok açıklamalarda bulunmaktadır (Aladağ 2013, 2014; Atıcı ve Çam 2013; Kıralp, 2015; Terzi, Tekinalp ve Leuwerke 2011). Her ne kadar RPD adaylarının bu kritik bilgi ve beceriler bakımından kendilerini geliştirebilmeleri üniversitede onlara sunulan eğitimin içeriği ve olanaklarına bağlı olarak gösterilse de mezun öğrencilerin bahsedilen bilgi ve becerilerine ilişkin düzeyleri ile ilgili durumu ortaya koyma niteliği taşıyan yeterli ampirik çalışmalara rastlanmamıştır. Nitekim birçok çalışma RPD programlarının çıktısı olan mezun RPD uzmanlarının, bahsedilen bu kritik bilgi ve beceriler bakımından ne düzeyde olduklarının araştırılması gerektiğini söylemektedir. Bu tarz çalışmalar, bahsedilen bilgi ve beceriler bakımından durum analizi yapılmasına imkan tanıyacaktır. Dolayısı ile var olan durumu ortaya koyarak olması gereken durum ile farkını hesaplamamızı sağlayacaktır. Bunun yanı sıra RPD programlarının donanımı, işleyişi, yöntemleri, materyalleri ve imkanları açısından bir ihtiyaç analizinin yapılmış olması RPD program revizyonu için açılım sağlayacaktır. Daha önce bahsedilen bu kritik bilgi ve becerilere ilişkin yeni mezun RPD uzmanının konu alındığı böyle bir durum ve ihtiyaç analizinin yapılmamış olması dikkat çeken 
önemli bir problemdir. Dolayısıyla, bu çalışma rehberlik ve psikolojik danışmanlık bölümünde öğrenim gören mezuniyet aşamasına gelmiş psikolojik danışman adaylarının bireyle psikolojik danışma ve rehberlik kuram ve yaklaşımlarına ve karar stratejilerine ilişkin yeterlik düzeylerini ortaya koymak ve literatürün bu değişkenler için belirlediği ölçütlerle kıyaslayarak bir ihtiyaç analizi yapmaktır. Araştırmanın bu temel amacı çerçevesinde; Kuzey Kıbrıs Türk Cumhuriyeti (KKTC)'nde özel bir üniversitede mezuniyet aşamasına gelmiş 4. sınıf lisans öğrencilerinin bireyle psikolojik danışmanlık kuramlarına ilişkin bilgi düzeylerini ve karar verme stratejilerini belirlemek amaçlanmıştır. Bu amaç doğrultusunda katılımcılardan ilgili bağımlı değişkenlere ilişkin elde edilen veriler ile bağımsız değişkenlere ilişkin veriler doğrultusunda analiz edilerek incelenmiştir. Bu inceleme aşağıda belirtilen araştırma soruları kapsamında yürütülmüştür. KKTC'de özel bir üniversitede RPD bölümünde öğrenim gören mezuniyet aşamasına gelmiş rehberlik ve psikolojik danışmanlık bölümü öğrencilerinin,

1. Bireyle psikolojik danışma kuram ve yaklaşımlarına ilişkin ölçülen bilgi düzeyleri ile alanyazın tarafından ilgili kuramlar için belirlenen standartlar arasında anlamlı farklılık var mıdır?

2. Karar stratejilerine ilişkin ölçülen yatkınlık düzeyleri ile alan-yazın tarafından karar stratejileri için belirlenen alt limitler arasında anlamlı farklılık var midır?

3. Bireyle psikolojik danışma kuram ve yaklaşımlarına ilişkin bilgi düzeyleri cinsiyet, kariyer planları ve farklı fırsat seçenekleri açısından anlamlı farklılık göstermekte midir?

4. Karar stratejilerine ilişkin yatkınlık düzeyleri cinsiyet, kariyer planları ve farklı fırsat seçenekleri açısından anlamlı farklılık göstermekte midir?

\section{Yöntem}

$\mathrm{Bu}$ çalışma nicel araştırma yöntemlerinden betimsel araştırma yöntemi kullanılarak yürütülmüştür. Araştırmanın amacına bağlı olarak belirlenen bağımlı ve bağımsız değişkenlere ilişkin veriler uygun psikometrik ölçme araçları kullanılarak toplanmış ve toplanan veriler durum analizi yapılabilmesine olanak tanımıştır. Mezuniyet aşamasına gelmiş RPD öğrencilerinin bireyle psikolojik danışma kuram düzeylerinin belirlenmesi ve karar verme stratejileri gibi bağımlı değişkenler ve ilgili bağımsız değişkenler açısından bir durum analizi yapma ihtiyacını gündeme getirmiştir. Durum analizi için uygun görülen yöntem betimsel yani tanımsal yöntemdir (Christensen, 1988).

\section{Örneklem}

Bu çalışmanın örneklemi, KKTC'de özel bir üniversitenin Eğitim Fakültesi'nde öğrenim gören Rehberlik ve Psikolojik Danışmanlık Bölümü öğrencilerinden oluşmaktadır. Burada birçok örnekleme yönteminden tabakalandırılmış seçkisiz örnekleme yönteminin (stratified random sampling method) kullanılması uygun bulunmuştur (Anastasi ve Urbina, 1997). Bunun sebebi, bağımsız değişkenlere ait farklı kategorilerin olması ve her kategorinin temsil edilebilmesi için orantılı seçki yapılma ihtiyacının olmasıdır. Basit seçkisiz yöntem kullanıldığında, her kategoriye ilişkin örnek bulma şansı düşmektedir. Hem her kategoriye ilişkin örnek bulmak adına hem de yansız seçki yapmak adına tabakalandırılmış seçkisiz örnekleme yöntemi kullanılmıştır. Kategorilere ait tüm katılımcıların eşit seçilme hakları saklı tutulmuştur (Anastasi ve Urbina, 1997). Öğrenciler araştırma konusu bakımından bilgilendirilmişler ve gönüllülük esasına bağlı olarak çalışmaya katkı koymak için davet edilmişlerdir. Mezuniyet aşamasına gelmiş 180 öğrencinin bağımsız değişkenlerin her kategorisine ilişkin dağılımını dağılım eğrisi üzerinde homojen kılmak için evrendeki 180 kişinin demografik bilgileri incelenerek katılımcıların 120'sine ulaşılmıştır. Ancak kullanılabilir geçerli yanıtlar bakımından 104 katılımcının girdisi dikkate alınmıştır.

\section{Veri Toplama Araçları}

Kişisel bilgi formu. Çalışmanın bağımsız değişkenleri ve katılımcıların demografik bilgileri hakkında sınıflama ve sıralama düzeyinde veri toplamak için geliştirilen bu form, çalışmada kullanılan diğer parametrik ölçme araçlarıyla birlikte oluşturulmuş kitapçı̆ı̆n ilk sorularından oluşmaktadır. Katılımcıların cinsiyetleri 
(Kadın ve Erkek), kariyer planları (Okul Psikolojik Danışmanı, Yüksek Lisans ve Psikolojik Danışman) ve mesleki aidiyet (Var ve Yok) durumları formun içerisindeki ilgili sorularla ölçülmüştür.

Bireyle psikolojik danışma kuram testi. Murdock (2013) tarafından oluşturulan 16 bölüm, her bölüm için 3 adet açık uçlu soru ve 161 adet çoktan seçmeli sorudan oluşan bir başarı testidir. Bu başarı testi Akkoyun (2013) tarafından Türkçe'ye uyarlanmıştır. Akkoyun, orijinali Murdock tarafından oluşturulmuş bu başarı testinin daha çok yüksek lisans düzeyine uygun olduğunu vurgulamış ve adaptasyon sürecinde maddelerin düzeyini lisans eğitimi düzeyine çekerek testin uygulama sahasını genişletmiştir. Yapılan uyarlama çalışması sonucunda 15 boyuta ilişkin Cronbach Alpha değerleri $\alpha=.76$ ile $\alpha=.88$ arasında değişkenlik göstermiştir (Akkoyun, 2013).

Murdock tarafından geliştirilmiş ve Akkoyun tarafından Türkçe'ye uyarlanmış bu başarı testi, çalışmanın amacı kapsamında hedef kitlenin seviyesine ve ölçülen değişken bakımından daha uygun hale gelebilmesi için 5 alan uzmanının olduğu bir komisyon tarafından değerlendirilmeye alınmıştır. Uzmanlar hem bireysel görüşlerini hem de komisyon olarak fikir birliğine vardıkları durumları dikkate alarak rapor hazırlamışlardır. Yürütülen kapsam geçerliği çalışması sonucunda uzmanlardan elde edilen veriye dayanarak orijinal testin bu çalışma kapsamında toplamda 10 boyuttan ve 50 çoktan seçmeli sorudan oluşan türevinin kullanılmasına karar verilmiştir. Bu bağlamda, kapsam bakımından KKTC'deki eğitim, kültür ve müfredat yapısına uygun soruların seçildiği testin yeni halinin boyutları, boyutlara ilişkin maddeleri ve Kapsam Geçerlik İndeksi (KGI) katsayıları sırasıyla Psikanalitik Kuram için KGİ=.89, Neoanalitik Yaklaşım için KGİ=.95, Bireysel Psikoloji için

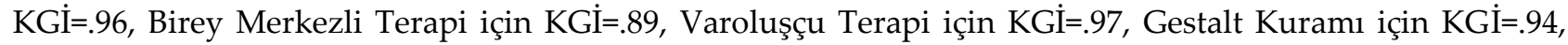
Davranışçı Kuram için KGI $=.79$, ADDT Kuramı için KGI $=.88$, Bilişsel Kuram için KGI= $=95$ ve Çözüm Odaklı Terapi için KGİ=.89 olarak hesaplanmıştır. Anastasi ve Urbina (1997) kapsam geçerliği çalışmalarında hesaplanan kapsam geçerlik indeksinin KGİ $>75$ kriterini sağlaması gerektiğini vurgulamıştır. Bu adaptasyon sonrası, kuramlara ilişkin başarıyı ölçecek olan başarı testi uygulama öncesi son halini almıştır. Buna göre, bu başarı testinin her boyutunda 5 adet çoktan seçmeli soru vardır. Her soru 2 puan değerindedir. Bir katılımcının her boyuttan alabileceği maksimum puan 10 iken testin tamamından alınabilecek en yüksek puan 100'dür. Kuram hakimiyeti bakımından katılımcıların her kuram için en az 6 ve testin toplamından ise en az 60 puan almaları gerekmektedir. Bu gereklilik uygulamanın yapıldığı üniversitenin yeterlik barajı veya geçme notu olarak bilinen $60^{\prime}$ a bağlıdır. Bu testin her boyutu için 6 notunun altında puan alınması olumsuz bağlamda yetersizliği, 6'nın üzerinde puan alınması ise yeterliği yani kurama hakim olduğu anlamına gelmekte ve bu şekilde yorumlanmaktadır.

Karar stratejileri ölçeği. Rehber ve psikolojik danışmanların istendik becerilere ne düzeyde sahip olduğunun belirlenmesinde tek bir ölçme aracının kullanılması iç güvenirliğin ve geçerliğin sağlanmasında yeterli olamaz (Anastasi ve Urbina, 1997; Ersever, 1996; Güçray, 1998). Bu sebeple işe koşulacak bir diğer envanter, Kuzgun (1993) tarafından geliştirilen Karar Stratejileri Ölçeği'dir. Bu ölçek karar stratejilerini dört farklı boyutuyla ölçmektedir. Bu boyutlar; içtepisel (10 soru), bağımlı (10 soru), mantıklı (10 soru) ve kararsızlık (10 soru) boyutlarıdır. Bu boyutlara ait sorular toplandığında 40 adet soru olduğu görülmektedir. $\mathrm{Bu}$ alt boyutlara ilişkin iç tutarlık katsayıları, yani Cronbach Alpha değerleri içtepisel için .74, mantıklı alt ölçeği için .72, bağımlı alt ölçeği için .55, ve kararsız alt ölçeği için .70 olarak hesaplanmıştır. Katılımcıların herhangi bir karar stratejisine sahip olma dereceleri, herhangi bir alt boyuttan aldıkları puanın 50 puanın üstünde olup olmamasına göre değişmektedir. 50 kesme puanı, Kuzgun (1993) yılında yapmış olduğu geçerlik ve güvenirlik çalışması kapsamında normal dağılım eğrisinin altında kalan alanların ordinant değerlerinin güven aralık katsayılarından yola çıkarak hesaplamıştır.

\section{Veri Analiz ve Yorumlama Prosedürleri}

Herhangi bir sayısal çözümleme tekniği kullanılmadan önce ön varsayımlar test edilmiştir. Değişkenlerin özelliklerine ve düzeylerine bağlı kalınarak yapılması öngörülen testlerin varsayımları doğrulandıktan sonra, sonuçlar değerlendirmeye alınmıştır. Bağımlı değişkenlerin, bağımsız değişkenlerin kategorilerine bağlı olarak sergiledikleri dağılım özellikleri ve genellenebilirlilik teorisi bağlamında gösterdikleri homojenlik özellikleri test edilerek ilgili parametrik ve parametrik olmayan sayısal çözümleme tekniklerine karar 
verilmiştir. Bu teknikler sırasıyla bağımsız gruplar için t-testi, tek örneklemli t-testi ve tek yönlü varyans analizi (ANOVA) teknikleridir. Null hipotezlerinin kabulü ve reddinde güven aralığı .95 ve hata olasıllı̆ı .05 olarak belirlenmiştir.

Tablo I

Bağıml Değişkenlerin Evren Özelliği Bakımından Normallik Testleri

\begin{tabular}{|c|c|c|c|c|c|c|}
\hline & \multicolumn{3}{|c|}{ Kolmogorov-Smirnova } & \multicolumn{3}{|c|}{ Shapiro-Wilk } \\
\hline & İstatistik & sd & Sig. & İstatistik & sd & Sig. \\
\hline PDRKH & ,322 & 100 & ,778 & ,759 & 100 & ,788 \\
\hline KS & ,277 & 100 & ,747 & ,749 & 100 & ,836 \\
\hline
\end{tabular}

PDRKH: Katılımcıların Psikolojik Danışmanlık ve Rehberlik Kuram Hakimiyetleri

KS: Katılımcların Karar Stratejileri

\section{Bulgular}

Araştırma Sorusu 1: KKTC'de özel bir üniversitede RPD bölümünde öğrenim gören mezuniyet aşamasına gelmiş rehberlik ve psikolojik danışmanlık bölümü öğrencilerinin, bireyle psikolojik danışma kuram ve yaklaşımlarına ilişkin ölçülen bilgi düzeyleri ile alan yazın tarafından ilgili kuramlar için belirlenen standartlar arasında anlamlı farklılık var midır?

Tablo II

Katılımcıların Psikolojik Danışmanlık Kuramlarına İlişkin Performanslarına Ait Yüzdelik Dağıllımları

\begin{tabular}{lccc}
\hline Psikolojik Danışmanlık & $\mathrm{n} \% \leq 5 \%$ & $\mathrm{n} \% \geq 6 \%$ & $\mathrm{n} \% \geq 60 \%$ \\
Kuramları & 49 & 51 & - \\
\hline Psikanalitik Kuram & 85,6 & 14,4 & - \\
Neoanalitik Yaklaşım & 82,7 & 17,3 & - \\
Bireysel Psikoloji & 93,3 & 6,7 & - \\
Birey Merkezli Terapi & 75 & 25 & - \\
Varoluşçu Terapi & 90,4 & 9,6 & - \\
Gestalt Kuramı & 60,6 & 39,4 & - \\
Davranışç Kuram & 79,8 & 20,2 & - \\
ADDT Kuramı & 75 & 25 & - \\
Bilişsel Kuram & 88,5 & 11,5 & - \\
Çözüm Odaklı Terapi & - & - & \\
Kuram Toplam & \multicolumn{2}{c}{} \\
\hline
\end{tabular}

KKTC'de özel bir üniversitede RPD bölümünde öğrenim gören mezuniyet aşamasına gelmiş RPD adaylarının bireyle psikolojik danışma kuram ve yaklaşımlarına ilişkin bilgi düzeyleri standardize edilmiş bir başarı testi ile ölçülmüş ve literatürün belirlemiş olduğu standartlarla kıyaslanmıştır. Buna göre, dikkate alınan 10 kuramın sadece bir tanesinde yani psikanalitik kuramda katılımclların \%51'inin yeterli bilgiye sahip olduğunu görülmüştür. Katılımcıların kuramlara ilişkin performanslarına ait aritmetik ortalamaları, standart sapmaları ve minimum standartlara ilişkin göreceli yüzdelik dağılımları (Tablo 2 ve Tablo 3) dikkate alındığında, diğer bütün kuramlarda katılımcıların çok büyük oranlarla istenilen minimum standartların altında performans gösterdikleri gözlemlenmektedir.

\section{Tablo III}

Katılımcıların Psikolojik Danışmanlık Kuramlarına İlişkin Performans Parametrelerine Ait Tek Örneklemli T-Testi Dağıllm Tablosu

\begin{tabular}{|c|c|c|c|c|c|}
\hline Psikolojik Danışmanlık Kuramları & $\bar{x}$ & (ss) & $(\mathrm{sh})$ & $\mathrm{t}$ & $\mathrm{p}$ \\
\hline Psikanalitik Kuram & $4,94^{\mathrm{a}}$ & 2,07 & ,203 & $-5,221$ & , 000 \\
\hline Neoanalitik Yaklaşım & $2,79 a$ & 1,86 & ,182 & $-17,633$ & ,000 \\
\hline Bireysel Psikoloji & $3,04^{a}$ & 2,18 & ,213 & $-13,877$ & ,000 \\
\hline Birey Merkezli Terapi & $2,42^{a}$ & 1,92 & 189 & $-18,957$ & ,000 \\
\hline Varoluşçu Terapi & $3,13^{a}$ & 2,34 & ,230 & $-12,464$ & ,000 \\
\hline Gestalt Kuramı & $2,83^{a}$ & 1,98 & 194 & $-16,321$ & ,000 \\
\hline Davranışçı Kuram & $4,04^{\mathrm{a}}$ & 2,43 & ,238 & $-8,234$ & ,000 \\
\hline ADDT Kuramı & $2,90^{a}$ & 2,19 & ,215 & $-14,403$ & ,000 \\
\hline Bilişsel Kuram & $3,44^{\mathrm{a}}$ & 2,58 & ,253 & $-10,124$ & ,000 \\
\hline
\end{tabular}


Tablo IV

Gökhan İSKIFOĞLU \& Tubanur ÇELIK İSKIFOĞLU

Katılımcıların Karar Stratejilerine İlişkin Performans Parametrelerine Ait Tek Örneklemli T-Testi Dağılım Tablosu

\begin{tabular}{|c|c|c|c|c|c|c|}
\hline Karar Stratejileri & & $\bar{x}$ & (ss) & $(\mathrm{sh})$ & $\mathrm{t}$ & $\mathrm{p}$ \\
\hline İçtepisel & & $36,36^{\mathrm{a}}$ & 7,66 & 75 & $-18,159$ & ,000 \\
\hline Mantıklı & & $43,35^{\mathrm{a}}$ & 7,11 & ,70 & $-9,538$ & ,000 \\
\hline Bağımlı & & $29,33^{a}$ & 4,74 & 46 & $-44,471$ &, 000 \\
\hline Kararsiz & & $33,82^{\mathrm{a}}$ & 8,68 &, 85 & $-19,004$ &, 000 \\
\hline \multicolumn{7}{|c|}{ a: Tek örneklemli t-testi için test değeri $=50$} \\
\hline Çözüm Odaklı Terapi & $2,71^{\mathrm{a}}$ & 1,87 & \multicolumn{2}{|c|}{183} & $-17,954$ & ,000 \\
\hline Kuram Toplam & $32,25^{b}$ & 9,53 & \multicolumn{2}{|c|}{,935 } & $-29,691$ & , 000 \\
\hline
\end{tabular}

a: Tek örneklemli t-testi için test değeri $=6$.

b: Tek örneklemli t-testi için test değeri $=60$.

Dikkate alınan ilk alt problem ve ona bağlı olarak geliştirilen hipotezin test edilebilmesi için sorulan araştırma sorusu işı̆̆ında elde edilen veriler tek-örneklemli t-testi ile analiz edilmiş ve literatür tarafından belirlenmiş başarı standardı ile karşılaştırılmıştır. Burada beklenen minimum başarı, her bir kuram için ortalama 6 puan ve toplam kuram için 60 puana eşittir. Buna göre katılımcıların tüm kuramlara ve kuram toplamlarına ilişkin standardize edilmiş başarı testinden elde ettikleri ortalamalarla olması gereken standart puanlar arasında negatif yönde anlamlı farklılık olduğu gözlemlenmiştir (Tablo 3).

Bu çalışma kapsamında dikkate alınan tüm psikolojik danışmanlık kuramlarına ilişkin katılımcıların performans parametreleri ile olması gereken değerler arasında anlamlı farklılık olmasından dolayı hiçlik hipotezi (H01: $\left.\mu_{1}>6 \& 60\right)$ ret edilerek alternatif hipotez $\left(\mathbf{H}_{\mathrm{a} 1:} \mu_{1}<6 \& 60\right)$ kabul edilmiştir.

Araştırma Sorusu 2: KKTC' de özel bir üniversitede RPD bölümünde öğrenim gören mezuniyet aşamasına gelmiş rehberlik ve psikolojik danışmanlık bölümü öğrencilerinin, karar stratejilerine ilişkin ölçülen yatkınlık düzeyleri ile alan-yazın tarafından karar stratejileri için belirlenen alt limitler arasında anlamlı farklılık var midır?

Tablo V

Katılımcıların Cinsiyetleri Açısından Psikolojik Danışmanlık Kuramlarına, Karar Stratejilerine ve Eleştirel Düşünme Ĕ̆ilimlerine İlişkin Ortalama ve Standart Sapma Puan Dă̆ıllmları

\begin{tabular}{lcc}
\hline & & Cinsiyet \\
\cline { 2 - 3 } Psikolojik Danışmanlık Kuramları & Kadın $(\mathrm{n}=52)$ & \multicolumn{1}{c}{ Erkek $(\mathrm{n}=52)$} \\
\hline Psikanalitik Kuram & $\bar{x}(\mathrm{ss})$ & $\bar{x}(\mathrm{ss})$ \\
Neoanalitik Yaklaşım & $5,00(2,08)$ & $4,88(2,07)$ \\
Bireysel Psikoloji & $3,27(1,73)$ & $2,31(1,87)$ \\
Birey Merkezli Terapi & $2,73(1,94)$ & $3,35(2,37)$ \\
Varoluşçu Terapi & $2,77(1,86)$ & $2,08(1,94)$ \\
Gestalt Kuramı & $3,62(2,57)$ & $2,65(2,10)$ \\
Davranışıı Kuram & $2,92(2,19)$ & $2,73(1,77)$ \\
ADDT Kuramı & $3,81(2,39)$ & $4,27(2,47)$ \\
Bilişsel Kuram & $3,23(2,45)$ & $2,58(1,87)$ \\
Çözüm Odaklı Terapi & $3,85(2,74)$ & $3,04(2,36)$ \\
Kuram Toplam & $2,62(1,80)$ & $2,81(1,95)$ \\
& $33,81(10,21)$ & $30,69(8,62)$ \\
\hline Karar Stratejileri & Kadın (n=52) & Erkek (n=52) \\
\hline İțepisel & $\bar{x}(\mathrm{ss})$ & $\bar{x}(\mathrm{ss})$ \\
Mantıklı & $37,06(8,13)$ & $35,65(7,18)$ \\
Bağımlı & $44,02(7,22)$ & $42,67(7,01)$ \\
Kararsız & $28,90(4,31)$ & $29,75(5,14)$ \\
Toplam & $31,67(7,84)$ & $35,96(9,02)$ \\
\hline
\end{tabular}

Katılımcıların kariyer stratejilerine ilişkin performansları Kuzgun (1993) tarafından geliştirilen Karar Stratejileri Ölçeği ile ölçülmüş ve 4 farklı alt ölçekle incelenmiştir. Toplanan veriye ilişkin dağılımın parametreleri dikkate alındığında katılımcıların en yatkın oldukları karar stratejisinin mantıklı karar verme stratejisi olduğu görülmektedir. Bunu sırasıyla içtepisel, kararsız ve bağımlı karar stratejileri izlemektedir (Tablo 3). Ancak, katılımcıların herhangi bir karar stratejisine sahip olmaları bakımından literatür tarafından ileri sürülen alt limit dikkate alındığında, katılımcıların karar stratejileri ölçeğinin hiç bir boyutunda beklenilen alt limitin üstüne çıkamadıkları gözlemlenmiştir. Tek örneklemli t-testi ile katılımcıların 
performansları literatürün belirlediği yeterlik ölçütü ile karşılaştırılmıştır. Karar stratejileri ölçeğinin tüm alt boyutlarına ilişkin negatif yönde anlamlı farklılık olduğu saptanmıştır (Tablo 4). Buna göre hiçlik hipotezi $\left(\mathbf{H}_{02}: \mu_{1}>50\right)$ reddedilerek alternatif hipotez $\left(\mathrm{H}_{\mathrm{a} 2}: \mu_{1}<50\right)$ kabul edilmiştir.

Araştırma Sorusu 3: KKTC' de özel bir üniversitede RPD bölümünde öğrenim gören mezuniyet aşamasına gelmiş rehberlik ve psikolojik danışmanlık bölümü öğrencilerinin, bireyle psikolojik danışma kuram ve yaklaşımlarına ilişkin bilgi düzeyleri cinsiyet, kariyer planları ve farklı fırsat seçenekleri açısından anlamlı farklılık göstermekte midir?

Katılımcıların bireyle psikolojik danışma kuram ve yaklaşımlarına ilişkin bilgi düzeyleri cinsiyet değişkeni açısından bağımsız gruplar t-testi ile incelendiğinde Neoanalitik Yaklaşım ve Varoluşçu Terapi dışında hiçbir kuram ve yaklaşımda anlamlı farklılık gözlemlenmemiştir. Neoanalitik Yaklaşım $t_{(102)}=2,720, p$ $=.008$ ve Varoluşçu Terapi $\mathrm{t}_{(102)}=2,127, \mathrm{p}=.036$ açısından kadınların akademik performansları erkeklere kıyasla kadınların lehine anlamlı farklılık göstermiştir (Tablo 5).

Katılımcıların bireyle psikolojik danışma kuram ve yaklaşımlarına ilişkin bilgi düzeyleri kariyer planları açısından tek yönlü varyans analizi (one-way analysis of variance) ile incelendiğinde, dikkate alınan 10 kuramın sadece bir tanesinde istatistiksel açıdan anlamlı farklılığa rastlanmıştır. Bu kuram Gestalt Kuramı'dır $\left(\mathrm{F}_{(3,100)}=4.425, \mathrm{p}=.006\right)$ Ayrıca katılımcların toplam kuram bilgisi, kariyer planları bakımından anlamlı farklılık göstermiştir $\left(\mathrm{F}_{(3,100)}=3.455, \mathrm{p}=.019\right)$. Diğer kuramlar açısından istatistiksel olarak herhangi bir anlamlı farklılı̆ga rastlanmamıştır.

Tablo VI

Katılımcıların Kariyer Planları Açısından Psikolojik Danışmanlık Kuramlarına İlişkin Ortalama ve Standart Sapma Puan Dağılımları

\begin{tabular}{|c|c|c|c|c|c|c|c|}
\hline \multirow{3}{*}{$\begin{array}{c}\text { Psikolojik Danışmanlık } \\
\text { Kuramları }\end{array}$} & \multicolumn{7}{|c|}{ Kariyer Planı } \\
\hline & $\begin{array}{c}\text { OPD } \\
(\mathrm{n}=77)\end{array}$ & \multicolumn{2}{|c|}{$\begin{array}{c}\mathrm{YL} \\
(\mathrm{n}=21)\end{array}$} & \multicolumn{2}{|c|}{$\begin{array}{c}\mathrm{PD} \\
(\mathrm{n}=3)\end{array}$} & \multicolumn{2}{|c|}{$\begin{array}{c}\text { ÇA } \\
(\mathrm{n}=3) \\
\end{array}$} \\
\hline & $\bar{x} \quad(\mathrm{ss})$ & $\bar{x}$ & (ss) & $\bar{x}$ & (ss) & $\bar{x}$ & (ss) \\
\hline Psikanalitik Kuram & $4,94 \quad(2,09)$ & 5,24 & $(1,95)$ & 4,67 & $(1,16)$ & 3,33 & $(3,06)$ \\
\hline Neoanalitik Yaklaşım & $2,49 \quad(1,72)$ & 3,62 & $(2,16)$ & 4,00 & $(2,00)$ & 3,33 & $(1,16)$ \\
\hline Bireysel Psikoloji & $2,94 \quad(2,09)$ & 3,71 & $(2,39)$ & 1,33 & $(1,16)$ & 2,67 & $(3,06)$ \\
\hline Birey Merkezli Terapi & $2,47 \quad(1,86)$ & 2,57 & $(2,20)$ & 2,00 & $(2,00)$ & 0,67 & $(1,16)$ \\
\hline Varoluşçu Terapi & $3,22 \quad(2,34)$ & 3,24 & $(2,49)$ & 2,67 & $(1,16)$ & 0,67 & $(1,16)$ \\
\hline Gestalt Kuramı & $2,65 \quad(1,85)$ & 2,86 & $(1,62)$ & 6,67 & $(4,16)$ & 3,33 & $(2,31)$ \\
\hline Davranışçı Kuram & $3,92 \quad(2,54)$ & 4,67 & $(1,93)$ & 5,33 & $(1,16)$ & 1,33 & $(1,16)$ \\
\hline ADDT Kuramı & $2,65 \quad(2,16)$ & 3,90 & $(2,05)$ & 1,33 & $(2,31)$ & 4,00 & $(2,00)$ \\
\hline Bilişsel Kuram & $3,30 \quad(2,67)$ & 4,00 & $(2,53)$ & 3,33 & $(1,16)$ & 3,33 & $(1,16)$ \\
\hline Çözüm Odaklı Terapi & $2,47 \quad(1,80)$ & 3,71 & $(1,71)$ & 2,67 & $(3,06)$ & 2,00 & $(2,00)$ \\
\hline Kuram Toplam & $31,04 \quad(8,82)$ & 37,52 & $(10,35)$ & 34,00 & $(12,17)$ & 24,67 & $(8,08)$ \\
\hline
\end{tabular}

Katılımcıların Gestalt Kuramı'na ve kuramlar toplamına ilişkin dağılımlarının homojenliği Levene Statistic ile kontrol edildiğinde, normal dağılıma kıyasla aralarında anlamlı farklılık olmadığı yani homojen dağıldıkları gözlemlenmiştir. İlgili bireyle psikolojik danışmanlık kuram ve yaklaşımının kariyer planının hangi düzeylerine ilişkin anlamlı farklılık gözettiğini tespit etmek amaçlı Post Hoc Test gruplarından Scheffe Testi yapılmıştır. Buna göre kariyer planı psikolojik danışman olan bireylerin Gestalt Kuramı'na ilişkin başarı düzeyleri, okul psikolojik danışmanı olmak isteyen $\mathrm{F}_{(3,100)}=4.425$, $\mathrm{p}=.006$ ve yüksek lisans yapmak isteyen $\mathrm{F}_{(3,}$, ${ }_{100)}=4.425, \mathrm{p}=.017$ bireylere kıyasla istatistiksel olarak anlamlı bir şekilde daha yüksek bulunmuştur (Tablo 6). Kuramlar toplamı bakımından değerlendirildiğinde ise kariyer planı yüksek lisans yapmak olan katılımcıların başarı ortalamaları lehine, kariyer planı okul psikolojik danışmanı olan katılımcıların başarı puanları arasında anlamlı farklılık olduğu görülürken $\mathrm{F}_{(3,100)}=3.455, \mathrm{p}=.048$ kariyer planlarına ilişkin diğer tüm kombinasyonlarda istatistiksel açıdan anlamlı farka rastlanılmamıştır (Tablo 6). Katılımcıların bireyle psikolojik danışma kuram ve yaklaşımlarına ilişkin bilgi düzeyleri ile mesleki tercih bakımından kararlılık düzeylerini incelemek için katılımcılara "Fırsat verilseydi 4 yıl önce başka bölümü tercih eder miydiniz?" 
sorusu sorulmuştur. Katılımcılar bu soruya "evet" veya "hayır" şeklinde yanıt vermişlerdir. "Evet" ve "hayır" diyenler arasında dikkate alınan 10 kurama ilişkin başarı oranları açısından anlamlı farklılık olup olmadığı bağımsız gruplar t-testi (independent samples t-test) ile test edilmiştir. Neoanalitik yaklaşımda $t(102)=-2.790, p$ $=.006$ "hayır" diyenlerin lehine, bireysel psikoloji $t_{(102)}=2.285, p=.024$ ve ADDT kuramı $t_{(102)}=-3.026, p=.003$ açısından "evet" ve "hayır" diyenler arasında "evet" diyenlerin lehine anlamlı farklılık olduğu bulunmuştur (Tablo 7).

\section{Tablo VII}

Katılımcıların Bölüme Aidiyetleri Açısından Psikolojik Danışmanlık Kuramlarına, Karar Stratejilerine ve Eleştirel Düşünme Eğilimlerine İlişkin Ortalama ve Standart Sapma Puan Dağılımları

\begin{tabular}{lcc}
\hline & & Aidiyet \\
\cline { 2 - 3 } Psikolojik Danışmanlık Kuramları & Var $(\mathrm{n}=62)$ & Yok $(\mathrm{n}=42)$ \\
\hline Psikanalitik Kuram & $\bar{x}(\mathrm{ss})$ & $\bar{x}(\mathrm{ss})$ \\
Neoanalitik Yaklaşım & $4,87(2,07)$ & $5,05(2,08)$ \\
Bireysel Psikoloji & $3,19(1,83)$ & $2,19(1,76)$ \\
Birey Merkezli Terapi & $2,65(2,11)$ & $3,62(2,18)$ \\
Varoluşçu Terapi & $2,58(2,03)$ & $2,19(1,76)$ \\
Gestalt Kuramı & $3,10(2,39)$ & $3,19(2,30)$ \\
Davranışç Kuram & $3,00(2,10)$ & $2,57(1,78)$ \\
ADDT Kuramı & $3,87(2,37)$ & $4,29(2,52)$ \\
Bilişsel Kuram & $3,39(2,39)$ & $2,19(1,64)$ \\
Çözüm Odaklı Terapi & $3,77(2,61)$ & $2,95(2,47)$ \\
Kuram Toplam & $2,65(1,87)$ & $2,81(1,88)$ \\
\hline Karar Stratejileri & $33,06(9,68)$ & $31,05(9,29)$ \\
\hline İçtepisel & $\bar{x}(\mathrm{ss})$ & $\bar{x}(\mathrm{ss})$ \\
Mantıklı & $36,85(8,48)$ & $35,62(6,30)$ \\
Bağımlı & $43,47(8,13)$ & $43,17(5,37)$ \\
Kararsız & $28,42(4,56)$ & $30,67(4,74)$ \\
Toplam & $33,27(8,87)$ & $34,62(8,44)$ \\
\hline
\end{tabular}

Araştırma Sorusu 4: KKTC' de özel bir üniversitede RPD bölümünde öğrenim gören mezuniyet aşamasına gelmiş rehberlik ve psikolojik danışmanlık bölümü öğrencilerinin, karar stratejilerine ilişkin yatkınlık düzeyleri cinsiyet, kariyer planları ve farklı fırsat seçenekleri açısından anlamlı farklılık göstermekte midir?

Katılımcıların karar stratejilerine ilişkin dağılımlarını cinsiyet değişkeni açısından incelemek için bağımsız gruplar t-testi yapılmış olup karar stratejilerinden sadece, kararsızlık stratejisine ilişkin kadınlarla erkekler arasında anlamlı farklılık gözlemlenmiştir $\left(t_{(102)}=-2.587, \mathrm{p}=.011\right)$. Buna göre erkeklerin kadınlara oranla karar verirken daha kararsız oldukları saptanmıştır. Aralarında anlamlı farklılık saptanmamasına rağmen kadınlar erkeklere oranla daha mantıklı kararlar alırken kadınların ve erkeklerin performans ortalaması bakımından en yüksek ortalamaya sahip oldukları karar stratejisi mantıklı karar stratejisi olarak görülmektedir (Tablo 5).

Tablo VIII

Katılımcıların Kariyer Planları Açısından Karar Stratejilerine İlişkin Ortalama ve Standart Sapma Puan Dağıllımları

\begin{tabular}{lccccc}
\hline & \multicolumn{5}{c}{ Kariyer Planı } \\
\cline { 2 - 6 } & $\begin{array}{c}\text { OPD } \\
(\mathrm{n}=77)\end{array}$ & $\begin{array}{c}\text { YL } \\
(\mathrm{n}=21)\end{array}$ & $\begin{array}{c}\text { PD } \\
(\mathrm{n}=3)\end{array}$ & $\begin{array}{c}\text { ÇA } \\
(\mathrm{n}=3)\end{array}$ \\
\hline Karar Stratejileri & $\bar{x}(\mathrm{ss})$ & $\bar{x}(\mathrm{ss})$ & $\bar{x}(\mathrm{ss})$ & $\bar{x}(\mathrm{ss})$ \\
\hline İctepisel & $36,16(7,59)$ & $37,67(8,40)$ & $42,00(6,08)$ & $36,67(6,66)$ \\
Mantıklı & $43,18(6,93)$ & $43,95(8,03)$ & $44,00(7,55)$ & $42,67(8,74)$ \\
Bağımlı & $29,55(4,79)$ & $27,95(4,48)$ & $31,33(5,51)$ & $31,33(4,51)$ \\
Kararsız & $34,36(8,66)$ & $33,14 \quad(9,36)$ & $28,33(4,51)$ & $30,00(7,21)$ \\
Toplam & $143,25(16,89)$ & $142,71 \quad(18,83)$ & $135,67(6,35)$ & $140,67(9,02)$ \\
\hline
\end{tabular}


Katılımcıların karar stratejilerine ilişkin dağılımlarını kariyer planları açısından karşılaştırarak incelemek için tek yönlü varyans analizi istatistiksel test tekniği kullanılmış olup kariyer planları açısından herhangi bir anlamlı farklılığa rastlanmamıştır (Tablo 8).

Katılımcıların karar stratejilerine ilişkin dağılımlarını mesleki tercih bakımından kararlılık düzeyleri açısından incelemek için bağımsız gruplar t-testi kullanılmıştır. Buna göre sadece bağımlı karar veren katılımcıların düzeyleri arasında "evet" diyenlerin lehine anlamlı farklılık saptanmıştır $\left(t_{(102)}=.773, p=.017\right)$. "Fırsat verilseydi 4 yıl önce farklı bölümde okur muydunuz?" sorusuna "evet" ve "hayır" diyen katılımcllar arasında diğer karar stratejileri açısından anlamlı farklılı̆̆a rastlanmamıştır (Tablo 7).

\section{Tartışma ve Öneriler}

KKTC'deki özel üniversitelerden bir tanesinin RPD bölümünde öğrenim gören mezuniyet aşamasına gelmiş son sınıf öğrencilerinin yeterlik düzeylerini bireyle psikolojik danışmanlık kuram hakimiyetleri ve karar stratejileri açısından incelemek, durum analizi yapmak ve ihtiyaçları belirlemek adına yürütülen bu çalışma, dikkate alınması gereken önemli bulgular ortaya çıkartmıştır.

Bilindiği gibi 21. yüzyılda gelişmekte ve değişmekte olan toplumlarda olduğu gibi ülkemizde de RPD alanının gereksinimi artarak devam etmektedir. Yaşlı nüfusa yönelik aile, kariyer danışmanlığı, okul öncesi, özel eğitim, ruh sağlı̆̆ı, rehabilitasyon alanlarında yelpaze genişleyerek devam etmektedir. Türkiye'de bu alanda bazı önemli gelişmeler gözlemlense de sunulan hizmetlerin henüz çok eksik olduğu bilinmektedir (Doğan, 2000b; Özaydın, 2001; Tan, 1990). Türkiye'ye ve KKTC'ye RPD alanı 'okul danışmanlığı' ile girmiştir. RPD'nin Türkiye ve KKTC'de en eski ve en güçlü olduğu alanın okul psikolojik danışmanlığı olmasına rağmen, bu alana baktığımızda okul psikolojik danışmanlığı olarak görev yapan öğretmenlerin yeterliklerinin sorgulandığını görmekteyiz (Bulut, 2007; Gündüz ve Çelikkaleli, 2009; Owen ve Owen, 2008). Literatürün geliştirdiği bu sorgulamaya rağmen var olan durumu amprik olarak ortaya koyan çalışmaların yetersizliği, RPD mesleğini icra eden profesyonel personelin bazı değişkenler açısından ihtiyaçlarının araştırılması gerekliliğini gündeme taşımıştır (Özbulak ve Serin, 2011; Özgün, 2007; Özgüven, 1990; Uslu ve Arı, 2005).

Bu mesleği etkin ve etkili icra etmenin literatür tarafından dikkate getirilen iki önemli değişkene bağlandığ1 görülmektedir. Bu çalışmanın giriş kısmında detaylı bir şekilde belirtildiği gibi bu değişkenler sırasıyla a) bireyle psikolojik danışma kuram hakimiyeti ve b) karar stratejileridir. RPD bölümünden yeni mezun olmuş bireylerin bu mesleği etkili icra edebilmeleri için kuram hakimiyetlerinin literatürün belirlediği standartların üzerinde olması gereklidir. Bu standartlar ise Kuzgun (1993) ve Murdock (2013) tarafından literatüre bağlı kalarak hazırladıkları bir başarı testi ile ölçülebilmektedir. Buna göre, belirlenen standartlara bağlı olarak geliştirilen başarı testinden alınması gereken minimum değerin 6 kat sayısı olduğu vurgulanmıştır. Karar stratejileri açısından düşünüldüğünde ise katılımcıların herhangi bir karar stratejisine sahip olabilme alt sınırının Kuzgun (1993) tarafından belirlenen 50 kat sayısı olduğu görülmüştür. Bu makale kapsamındaki katılımcıların performanslarının ilgili iki değişkenin düzeyleri açısından belirlenen yeterlik limitlerinden anlamlı düzeyde farklılaştığı ve bu farklılaşmanın olumsuz yönde olduğu saptanmıştır. Bu sonuçlar, nedenlerinin açıklanması ve tartışılması gerekliliğini gündeme getirmektedir. Bu bağlamda, literatür derinlemesine araştırıldığında bu sonuçların ortaya çıkış sebeplerinin başında öğrencilerin bu bölümü seçme nedenleri geldiği yönündedir. Kolay atanabilme, daha çabuk iş bulabilme ve para kazanma kaynağı olarak popüler görülen mesleklerin tercih edilmesi, bu bölümlerde okuyan öğrencilerin çoğunun yeterli donanıma sahip olamadan mezun olmalarıyla sonuçlanmaktadır (Doğan, 2000b; Dost ve Keklik, 2012; Korkut, 2007). Diğer yandan üniversitelerin bölümlere öğrenci alırken bireylerin giriş davranışlarını kriter olarak almamaları, sadece merkezi yerleştirme sınav sonuçlarına bakarak öğrencileri ilgili bölümlere kabul etmeleri var olan olumsuz durumun devamlılı̆̆ını sağlamaktadır (Jones, 2013; Owen ve diğerleri; Yayla ve İkiz, 2017; Yılmaz, Dursun, Pektaş ve Altay; 2012).

İlgili değişkenler açısından incelendiğinde, bu bölümde okuyan öğrencilerin kendilerini sürekli yenilemeleri ve gelişmelere açık hale getirmeleri gerekmektedir. Örneğin; psikolojik danışmanlar danışanlarının kendilerini keşfetmelerini sağlamak için cesaretlendirilirler, kendilerini yönetme becerilerini geliştirirler ve etik değerleri benimseyen bir dünya vatandaşı olmalarını sağlamaya çalışırlar. Bunları yapmaya 
çalışan bir danışmanın da sürekli kendisini yetiştirme çabası içerisinde olması gerekir. Bir kişinin bu çabayı gösterebilmesi, kişide var olan içsel motivasyona bağlıdır. Sadece popülist düşüncelerle bölümde öğrenci olan kişilerden böylesi bir motivasyona sahip olmaları beklenemez. Dolayısıyla, yapılan çalışmalar Türkiye ve KKTC'de psikolojik danışmanların kariyer alanında yeterli ilerlemeye sahip olmadıkları yönündedir (Atik, Arıcı ve Ergene, 2014; Egan, 2014; Yayla ve İkiz, 2017).

Bu durumu açıklama niteliği olan bir diğer önemli durum, lisans düzeyinde verilen süpervizyon hizmetlerinin yetersizliğidir. Bu araştırmada detaylı yer verildiği üzere, verilen süpervizyon hizmetleri yetersiz olduğundan dolayı bireylerin yeteneklerinin farkına varmaları ve geliştirmeleri zorlaşmaktadır (Cashwell ve Dooley, 2001). Bu duruma süpervizörlerin bu açıdan gerekli hassasiyeti göstermeleri bağlamında yeterli fiziksel ve akademik donanıma sahip olmayışları eklendiğinde öğrencilerin yeterli süpervizyon almaları imkansızlaşmaktadır (Gümüş, 2015). Bununla birlikte üniversitelerde RPD odalarının fiziki koşullarının uygun olmadığı ve kullanılan ölçeklerin yetersiz olduğu ya da dilimize tam uygun uyarlanamadığı dikkate alınırsa öğrencilerden kendilerini ilgili alanlarda geliştirmelerini beklemek zorlaşmaktadır (Akkoyun, 1995; Corey, 2007; Çetinkaya ve Karaırmak, 2012; Dye ve Borders, 1990; Meydan, 2014; Yayla ve İkiz, 2017; Y1lmaz ve Acar, 2015).

$\mathrm{Bu}$ çalı̧̧ma kapsamındaki katılımcıların, literatürün belirlediği standartların altında performans göstermelerinin bir diğer sebebi de verilen eğitimin bilgi ve kavrama düzeyinin üzerine çıamaması ve ölçme değerlendirmenin yine bu düzeylerde kalmasıyla açıklanması muhtemeldir (Deniz, 2015). Çoğunlukla düz anlatım yönteminin kullanıldığı, öğrencilerin pasif alıcı konumunda olduğu, sınavların ekseriyetle çoktan seçmeli sorularla yapıldığ 1 , öğrencilerin kendilerini ifade edebilmelerine olanak tanınmadığı, kuramlara ilişkin terapötik süreçlerin sadece kitaplar aracılığıyla tartışıldığı ve öğrencilerin teoriyi pratiğe dönüştürerek terapötik süreçlere ilişkin anlamlı öğrenmeyi tecrübe edemediği bir eğitim-öğretim ortamının, literatürün ilgili değişkenler açısından belirlediği standartların üzerinde çıktılar sergilemesi beklendik bir durum değildir (Aladağ ve Bektaş, 2009; Aladağ, Yaka ve Koç, 2014; Bilgiç, 2011).

Katılımcıların bireysel psikolojik danışma kuram ve yaklaşımlarına ve karar stratejilerine ilişkin ölçülen değerleri katılımcıların cinsiyetleri, kariyer planları ve mesleki tercihleri gibi farklı kategorik değişkenler açısından incelendiğinde ilginç sonuçlarla karşılaşılmıştır. Örneğin, kadınlar neoanalitik ve varoluşçu kurama ait ölçülen değerler bakımından erkeklerden anlamlı düzeyde daha iyi performans sergilemişlerdir. Her ne kadar diğer bütün kuram türlerinde kadınlar daha yüksek puanlar almış olsa da, sadece bu iki kuramda anlamlı farklılığa rastlanmıştır. Bu durum, kadın psikolojik danışman adaylarının erkek psikolojik danışman adaylarına kıyasla daha analitik düşünmelerine bağlanabileceği gibi katılımcı kadınların katılımcı erkeklere kıyasla daha fazla özgüven algısına sahip olmalarıyla da açıklanabilir. Bu bulgu, akıllara bu mesleği kadınların erkeklere kıyasla daha başarılı icra edebileceklerine ilişkin varsayımları getirmektedir. Sadece bu çalışmanın bulgularına dayanarak böyle bir genelleme yapmak imkansız olsa da bu tema ile ilgili bundan sonraki çalışmaların bu varsayım temelinde cinsiyet değişkenini incelemeleri gerekliliği önem arz etmektedir.

Cinsiyetle ilgili bir diğer önemli bulgu, erkeklerin kadınlara oranla daha kararsız oldukları yani karar stratejisi bakımından erkeklerin kararsız olduğu yönündedir. Kadınlar ise erkeklere kıyasla daha mantıklı karar verme eğilimi taşımaktadırlar. Cinsiyetin karar stratejileri ile çapraz karşılaştırılması neticesinde ortaya çıkan tek anlamlı fark karar stratejisinin alt boyutlarından biri olan kararsızlık boyutunda erkeklerin lehinedir ve Lam, Tracz ve Lucey (2013)'in yürüttükleri çalışma bu bulguyu desteklemektedir.

Bu çalışma kapsamında dikkate alınan bir diğer bağımsız değişken katılımcıların kariyer planları idi. Bu değişken açısından incelendiğinde kariyer planı psikolojik danışmanlık olan katılımcılar, kariyer planı okul psikolojik danışmanı olan ve yüksek lisans yapmak olan katılımcılardan Gestalt Kuramı'na ilişkin performansları bakımından anlamlı düzeyde farklılaşmışlardır. Katılımcıların kariyer planı ile diğer tüm kuramlara ilişkin bilgileri bakımından anlamlı farklılığa rastlanmadığı gibi karar stratejileri bakımından da herhangi bir anlamlı farklılık gözlemlenmemiştir.

Bulguların literatür tarafından eşleştirilemediği diğer bir deyişle literatürde örneğine rastlanmadığı bir diğer bulgu serisi ise katılımcıların "Fırsat verilseydi 4 yıl önce başka bölümde okurdum." sorusuna verdikleri 
evet veya hayır yanıtları ile bireyle psikolojik danışma kuramlarına ve karar stratejilerine ilişkin gösterdikleri performansların farklılaşma boyutlarıdır. Örneğin, bu soruya hayır diyenlerin neoanalitik, bireysel psikoloji ve ADDT kuramında, bu soruya evet diyenlere kıyasla anlamlı düzeyde daha yüksek performans gösterdikleri gözlemlenmiştir. Bu bulgu, bu çalışmanın en ilginç bulgularından biridir ve diğer bulgularla bir araya geldiğinde yapbozun parçaları gibi bir bütün oluşturmaktadırlar.

Son olarak, bu çalışmadan elde edilen bulguların geçerliğini, güvenirliğini ve genellenebilirliğini arttırabilmek adına, bu çalışmanın daha geniş bir örneklemle daha fazla üniversitede uygulanması ve sonuçlarının karşılaştırılması önerilmektedir. Ayrıca bir diğer önemli nokta, literatürün önemle vurguladığı değişkenlere olumlu yönde etki etme açısından geniş kapsamlı bir proje dahilinde geliştirilecek bir programın etkililiğinin test edilmesidir.

\section{Kaynaklar}

Akkoyun, F. (1995). RPD'de ünvan ve program sorunu: Bir inceleme ve öneriler. Psikolojik Danışma ve Rehberlik Dergisi, 2(6), 1-21.

Akkoyun, F. (2013). Psikolojik danışma ve psikoterapi kuramları. Ankara: Nobel Yayınları.

Aladağ, M. (2013). Counseling skills pre- practicum training at guidance and counseling undergraduate programs: A qualitative investigation. Educational Sciences, 13(1), 72-79.

Aladağ, M. (2014). Psikolojik danışman eğitiminin farklı düzeylerinde bireyle psikolojik danışma uygulaması süpervizyonunda kritik olaylar. Ege Eğitim Dergisi, 2(15),428-475.

Aladağ, M. ve Bektaş, D.Y. (2009). Examining individual- counseling practicum in a Turkish undergraduate counseling program. Ĕ̆itim Araştırmaları, 37, 53-70.

Aladağ, M., Yaka, B. ve Koç, İ. (2014). Psikolojik danışma becerileri eğitimine ilişkin psikolojik danışman adaylarının görüşleri. Kuram ve Uygulamada Eğitim Bilimleri, 14(3),859-886.

Alver, B. (2004). Psikolojik danışma ve rehberlik eğitimi alan öğrencilerin empatik beceri ve karar verme stratejilerinin çeşitli değişkenlere göre incelenmesi. Kazım Karabekir Eğitim Fakültesi Dergisi, 10, 185-205.

Anastasi, A. ve Urbina, S. (1997). Psychological testing, USA, NY: Prentice-Hall.

Atıc1, M. ve Çam,S. (2013). Okullarda RPD uygulamaları dersine ilişkin görüşlerinin incelenmesi. Türk Psikolojik Danışma ve Rehberlik Dergisi, 4(39), 106-119.

Atik, Z.E., Arıcı, F. ve Ergene, T. (2014). Süpervizyon modelleri ve modellere ilişkin değerlendirmeler. Türk Psikolojik Danışma ve Rehberlik Dergisi, 5(42), 305-317.

Avşaroğlu, S. (2007). Üniversite öğrencilerinin karar vermede özsaygı karar verme ve stresle başa çıkma stillerinin benlik saygısı ve bazı değişkenler açısından incelenmesi (Yayımlanmamış doktora tezi). Selçuk Üniversitesi, Konya.

Bilgiç, H. S. (2011). Rehber öğretmenlerin (psikolojik danışmanları) öz yeterlilikleri (Yayımlanmamış yüksek lisans tezi). Doğu Akdeniz Üniversitesi, KKTC.

Bilgin, M. (2000). Psikolojik danışma ve rehberlik eğitiminde çağdaşlaşma. Çukurova Üniversitesi Sosyal Bilimler Dergisi, $6(6), 21-36$.

Bulut, N. (2007). Okul psikolojik danışmanlarının yaşam doyumu stresle başa çıkma stratejileri ve olumsuz otomatik düşünceleri arasındaki ilişkiler. Türk Psikolojik Danışma ve Rehberlik Dergisi, 3(27), 1-13.

Cashwell, T. H. ve Dooley, K. (2001). The impact of supervision on counselor self efficacy. The Journal of Supervision in Psychoterapy and Mental Healt, 20(1), 39-47.

Christensen, L. B. (1988). Experimental methodology (4. bs.). Newton, MA: Allyn and Bacon.

Corey, G. (2007). Psikolojik Danısma, Psikoterapi Kuram ve Uygulamaları. (Çev. Tuncay Ergene) Ankara: Mentis Yayıncilik. 
Çetinkaya, R. S. ve Karaırmak, Ö. (2012). Psikolojik danışman eğitiminde süpervizyon. Türk Psikolojik Danışma ve Rehberlik Dergisi, 4(37),107-119.

Deniz, M. E. (2015). Kuramlarda uygulamalar: Yıldız Teknik Üniversitesi örneği. Psikolojik Danışma ve Rehberlik Dergisi, $24(1), 57-65$.

Doğan, S. (2000a). Psikolojik danışman eğitiminde akreditasyonun gereği ve bir model önerisi. Türk Psikolojik Danışma ve Rehberlik Dergisi, 2(14), 31-38.

Doğan, S. (2000b). Türkiye'de psikolojik danışma ve rehberliğin durumu ve geleceğe ilişkin yönelimler. Eğitim ve Bilim Dergisi, 25(118), 3-8.

Dost, M. T. ve Keklik, İ. (2012). Alanda çalışanların gözünden psikolojik danışma ve rehberlik alanının sorunları. Mehmet Akif Ersoy Üniversitesi Eğitim Fakültesi Dergisi, 12(23), 389-407.

Dye, H. A. ve Borders L. D. (1990). Counseling supervisors: standars for preparation and practice, USA, NY: American Counseling Association.

Egan, G. (2011). Psikolojik danışma becerileri. (Çev. Ö. Yüksel). İstanbul: Kaknüs Yayınları.

Egan, G. (2014). Danışma Becerileri Üzerine Alıstırmalar. (Çev. Müzeyyen Baturay) İstanbul: Kaknüs Yayınları.

Eldeleklioğlu, J. (1999). Karar stratejileri ile ana baba tutumları arasındaki ilişki. Türk Psikolojik Danışma ve Rehberlik Dergisi, 2(11), 7-13.

Ersever, H. Ö. (1996). Karar verme becerileri kazandırma programının ve etkileşim grubu deneyiminin üniversite öğrencilerinin karar verme stilleri üzerindeki etkileri (Yayınlanmamış doktora tezi). Ankara Üniversitesi, Ankara.

Gibson, R. L. ve Mitcell, M. H. (1990). Introduction to counseling and guidance (6. bs.). New York: MacMillian Publ. Comp.

Gladding, S. T. (2013). Psikolojik danışma- kapsamlı bir meslek. (Çev. Nilüfer Voltan Acar). Ankara: Nobel Yayınları.

Güçray, S. S. (1998). Bazı değişkenler, algılanan sosyal destek ve atılganlığın karar verme sitilleri ile ilişkisi. Psikolojik Danışma ve Rehberlik Dergisi, 2(9), 7-17.

Gümüss, A. E. (2015). Bireyle psikolojik danışma uygulaması dersi kapsamında süpervizyon deneyimlerimiz: Bir vakıf üniversitesi örneği. Türk Psikolojik Danışma ve Rehberlik Dergisi, 15(2), 29-43.

Gündüz, B. ve Çelikkaleli, Ö. (2009). Okul psikolojik danışmanlarında mesleki yetkinlik inancı. Mersin Üniversitesi Ĕ̆itim Fakültesi Dergisi, 5(1), 119-133.

Hastie, R. ve Dawes, R. M. (2010). Rational choice in an uncertain world: The psychology of judgment and decision making. Los Angeles: Sage.

Hatipoğlu, H. (2010). Okullarda yürütülen psikolojik danışma ve rehberlik uygulamalarının belirlenmesi ve bazı değişkenler açısından incelenmesi (Yayınlanmamış yüksek lisans tezi). Çukurova Üniversitesi, Adana.

Jones, R. N. (2013). Temel psikolojik danışma becerileri. (Çev. F. Gamze Sart). Ankara: Nobel Yayınları.

Kıralp, F. Ş. Ş. (2015). Do courses taken from psychological counseling departments affect the trainee counselor's selfefficacy?. Social and Behavioral Sciences, 205(2), 637-641.

Korkut, F. (2007). Psikolojik danışmanların mesleki rehberlik ve psikolojik danışmanlık ile ilgili düşünceleri ve uygulamaları. Hacettepe Üniversitesi Ĕ̆itim Fakültesi Dergisi,(32)3, 187-97.

Kuzgun, Y.(1993). Karar stratejileri ölçeği: Geliştirilmesi ve standardizasyonu, VII. Ulusal psikoloji bilimsel çalısmaları, Ankara: Türk Psikologlar Derneği.

Kuzgun, Y. (2000). Meslek Danışmanlığı, kuram ve uygulamalar. Ankara: Nobel Yayınları.

Kuzgun,Y. (2011). Meslek rehberliği ve danışmanlığına girişs. Ankara: Nobel Yayınları. 
Lam, S., Tracz, S. ve Lucey, C. (2013). Age, gender, and ethnicity of counselor trainees and corresponding counselling self-efficacy: Research findings and implications for counsellor educators. Int J Adv Counselling, 35, 172-187

Meydan, B. (2015). Bireyle psikolojik danışma uygulamasında Mikro Beceri Süpervizyon Modeli'nin etkililiğinin incelenmesi. Türk Psikolojik Danışma ve Rehberlik Dergisi, 5(43), 55-68.

Meydan,B. (2014).Psikolojik danışman adaylarına psikolojik danışma becerilerinin kazandırılması: Karşılaştırmalı bir inceleme. Hacettepe Üniversitesi Ĕ̆itim Fakültesi Dergisi, 29 (3), 110-123.

Murdock, N. L. (2013). Psikolojik danışma ve psikoterapi kuramları (F. Akkoyun, Çev.) Ankara: Nobel Yayınları.

Niles, S. G. ve Bowlsbey, J. H. (2013). 21. yüzyılda kariyer gelişimi müdahaleleri (Çev. F. Korkut Owen), Ankara: Nobel Yayınları.

Owen F., Acar, T., Avcı Ö. H. ve Kızıldağ S. (2013). Psikolojik danışma ve rehberlik programlarının mezunlar tarafından değerlendirilmesi. Türk Psikolojik Danışma ve Rehberlik Dergisi, 19(2), 354-372.

Owen, F. K. ve Owen, D. W. (2008). Okul psikolojik danışmanlarının rol ve işlevleri: Yöneticiler ve psikolojik danışmanların görüşleri. Ankara Üniversitesi Ĕ̆itim Bilimleri Fakültesi Dergisi, 41(1), 207-221.

Owen, F. K., Dost, M. T. ve Bugay, A. (2014). Psikolojik danışman eğitimcilerinin psikolojik danışman adaylarının mesleğe ilişkin kişisel eğilimleri hakkındaki görüşleri. International Journal of Human Sciences, 11(1), 1037-1055.

Öncü, H. (2015). Psikolojik danışma müdahalesi olarak bireysel psikolojik danışma. Ahi Evran Üniversitesi Kırşehir Eğitim Fakültesi Dergisi, 16(1), 389-407.

Özaydın, A. (2001). Resmi ilköğretim okullarında yönetici, rehber öğretmen ve sınıf öğretmenlerinin görüşlerine göre rehberlik uygulamaları (Yayınlanmamış yüksek lisans tezi). Yıldız Teknik Üniversitesi, İstanbul.

Özbulak, B. E. ve Serin, N. B. (2011). Okul psikolojik danışmanlarının problem çözme ve sosyal beceri düzeylerinin incelenmesi. Hacettepe Üniversitesi Eğitim Fakültesi Dergisi, 41(3), 302-312.

Özgün, M. S. (2007). Okul psikolojik danışmanlarının kişilik özellikleri ile mesleki yetkinlik beklentileri arasındaki ilişkinin incelenmesi (Yayınlanmamış yüksek lisans tezi). Doğu Akdeniz Üniversitesi, KKTC.

Özgüven, İ. E. (1990). Ülkemizde psikolojik danışma ve rehberlik faaliyetlerinin dünü ve bugünü. Psikolojik Danışma ve Rehberlik Dergisi, 1(1), 4-15.

Öztürk, A. (2014). Rehberlik ve psikolojik danışmanlık programı 1. sınıf öğrencileriyle 4. sınıf öğrencilerinin psikolojik danışma öz- yeterlik inançları. Elektronik Sosyal Bilimler Dergisi, 13(51), 255-272.

Özyürek, R. (2009). Okullarda psikolojik danışma ve rehberlik uygulamaları ve öğrencilere sağlanan süpervizyon olanakları: Ulusal bir tarama çalışması. Türk Psikolojik Danışma ve Rehberlik Dergisi, 4(32), 54-63.

Pamuk, M. (2012). Psikolojik danışmanların psikolojik danışma uygulamalarına ve uygulamalarda kendi yeterliklerine ilişkin algıları (Yayınlanmamış yüksek lisans tezi). Marmara Üniversitesi, İstanbul.

Sarıkaya, T. ve Khorshid, L. (2009). Üniversite öğrencilerinin meslek seçimini etkileyen etmenlerin incelenmesi: Üniversite öğrencilerinin meslek seçimi. Türk Eğgitim Bilimleri Dergisi, 7 (29), 393- 423.

Sharf, R. S. (2014). Psikoterapi ve psikolojik danışma kuramları (Çev. N.V. Acar), Ankara: Nobel Yayınları.

Sharpley, F. C. ve Ridgway, R. I. (1991). The relevance of previous knowledge of psychology to training in basic counseling skills. Counselor Education and Supervision, 19(3), 298-306.

Tan, H. (1990). Okullarımızda psikolojik hizmetlerin neresindeyiz. Türk Psikolojik Danısma ve Rehberlik Dergisi, 1(1), 2731.

Terzi, Ş., Tekinalp, B. E. ve Leuwerke, W. (2011). Psikolojik danışmanların okul psikolojik danışma ve rehberlik hizmetleri modeline dayalı olarak geliştirilen kapsamlı psikolojik danışma ve rehberlik programın değerlendirmeleri. Hacettepe Üniversitesi Eğitim Fakültesi Dergisi, 41(3), 51-60. 
Tiryaki, M.G. (1997). Üniversite öğrencilerinin karar verme davranışlarımın bazı değişkenler açısından incelenmesi (Yayımlanmamış yüksek lisans tezi). Hacettepe Üniversitesi, Ankara.

Tyburski, E. (2017). Psychological determinants of decision-making. Neuroeconomic and Behavioral Aspects of Decision Making, 22(1), 19-34.

Uslu, M. ve Arı, R. (2005). Psikolojik danışmanların danışma becerisi düzeylerinin incelenmesi. Selçuk Üniversitesi Sosyal Bilimler Enstitüü̈ Dergisi, 14, 509- 519.

Yaka, B. (2005). Psikolojik danışmanların temel psikolojik danışma becerilerine ilişkin yeterlik düzeylerinin bazı değişkenlere göre incelenmesi (Yayımlanmamış yüksek lisans tezi). Hacettepe Üniversitesi, Ankara.

Yayla, E. ve İkiz, F. E. (2017). Psikolojik danışmanların etkili nitelikleri ile danışma öz-yeterlik düzeyleri arasındaki ilişki. Türk Psikolojik Danışma ve Rehberlik Dergisi, 7(48), 31-34.

Yeşilyaprak, B. (2009). Türkiye'de psikolojik danışma ve rehberlik alanının geleceği: Yeni açılımlar ve öngörüler. Ankara Üniversitesi Ĕ̆itim Fakültesi Dergisi, 42(1),193-213.

Yılmaz, İ.A., Dursun, B., Pektaş, K. ve Altay, A. (2012). Üniversite öğrencilerinin kariyer seçimlerinin demografik özellikler açısından incelenmesi: Pınarhisar MYO örneği. Elektronic Journal of Vocational Colleges, 2(2), 9-21.

Yılmaz, O. ve Acar, N.V. (2015). Psikolojik danışman eğitiminde süpervizyonun önemi ve grupla psikolojik danışmadaki rolü. Abant İzzet Baysal Üniversitesi Eğitim Fakültesi Dergisi, 15(1),341-356. 


\section{EXTENDED ABSTRACT}

\section{Introduction}

It is well known that Guidance and Psychological Counselling students have variety of career choices following graduation. Some of these include running psychological counselling services, becoming school counsellor, providing career guidance, studying for graduate research, becoming academician at universities, carrying out independent research and providing family guidance at private sector. The successes counsellors achieve in their fields inevitably affect the success of students at schools and individuals in societies. Those who are provided with decent counselling services regarding to their educational and life experiences is believed to be happier individuals in their educational and personal lives. This is directly associated with being involved in positive relationships with family, society and school members. Receiving decent psychological support is significant for both social and personal wealth. Wealthy families will produce psychologically well children and in turn will affect society in a positive sense. For counsellors and psychologists to be successful in that sense strictly depends on the sort of education and the academic basement they would build at their faculties. Many research and researchers are in favour of the idea that counsellors' effective counselling abilities can mostly be developed at universities and their capabilities of providing good counselling services is highly associated with certain skills that should be developed at universities. Scholars strongly assert that these critical knowledge and abilities are such that form scientific virtue of a person where they will build their experiences as they use them. Likewise, those who cannot gain the kind of virtue will not be able to develop a baseline to build experiences for helping, guiding and providing beneficial supports to others in societies.

\section{Method}

This research focuses on extracting the extent to which graduated psychological counsellors convey the socalled abilities and convey the critical knowledge required for successful counselling procedure. For that matter the following research questions have been addressed.

1. Is there a significant difference between the standards set by the literature for newly graduated guidance and psychological counsellors regarding their knowledge in individual psychological counselling theories and measured outcomes of students recently graduated from Department of Guidance and Psychological Counselling from a University in Turkish Republic of Northern Cyprus (TRNC)?

2. Is there a significant difference between the standards set by the literature for newly graduated guidance and psychological counsellors regarding their dispositions towards decision making strategies and measured outcomes of students recently graduated from Department of Guidance and Psychological Counselling from a University in TRNC?

3. Is there a significant difference between participants' knowledge in individual psychological counselling theories regarding to their gender, carrier plans and various opportunity choices that they have developed?

4. Is there a significant difference between participants' dispositions towards various decision-making strategies regarding to their gender, carrier plans and various opportunity choices that they have developed?

In order to address the above research questions, this research has utilized a descriptive approach to the study. For that reason, critical variables have been carefully defined and literature for gathering empirical data were surveyed to extract the necessary inventories to collect data regarding to those variables being researched. For respective analysis, inventories and psychometric data collection procedures were utilized to collect reliable and valid data.

The sample of this study has been established by a group of voluntarily selected students who were about to graduate from the department of guidance and psychological counselling from a university in TRNC. 
Among the many sampling procedures, stratified random sampling procedure was preferred to use to define the study sample for this research for several reasons. First, there were many different sub categories regarding the independent variables being studied and to collect homogenous data from subsets of those variables there must have been balanced selection of participants for each category of those variables. Prior to that sampling procedure, students in the faculty were informed about the scope of the study and were informed that their participation is entirely voluntary and that they can reject to be a part of this study. Therefore, 180 students wanted to voluntarily participate in the study but only 120 of them were reached during the course of data collection. However, only 104 participants' participation was found to be reliable and considered for that research.

\section{Results}

The key results of this research has recorded that the assessed knowledge of newly graduated students regarding to individual psychological counselling theories are quite lower than the standards set by the literature for minimum effect. Moreover, students who are recently graduated from the department of guidance and psychological counselling have recorded to possess no one of the defined decision making strategies at all. Research also showed that participants of this study have not yet developed a positive inclination towards a specific decision making strategy. In addition to that there were negatively significant difference between the standards set by the literature and the measured outcomes of the participants regarding to both critical dependent variables.

When the results were interpreted by the participants' demographic information, the results for gender showed that women performed significantly better than men in Neo-analytical Approach $t(102)=2,720, p=, 008$ and in Existentialist approach $\mathrm{t}(102)=2,127, \mathrm{p}=, 036$. No significant differences were observed for other demographic variables such as career plans and decisions of satisfaction regarding to the profession they have chosen across the dependent variables of the study.

\section{Conclusion}

Women performed better than men in terms of their knowledge in Neo-analytical and Existential theories in counselling. Although women always performed better than man in the sense of knowledge regarding to other counselling theories, significant difference in favour of women was only recorded for the specified theories. This key finding can be linked to the notion that women can think even more critical than men in most cases, and this finding brings to mind the assumption that women might be better psychological counsellors than men. It is suggested for further researchers to consider the cons of this work to conclude with stronger generalizations regarding the gender issue and competencies of students in guidance and psychological counsellor departments in various different universities. 